\title{
生産計画を考慮した作業者の教育計画の作成手法に関する研究
}

\author{
岩村 幸治"1，西濱 大佑 ${ }^{* 2}$ ，田中 健太郎 ${ }^{* 1}$ ，谷水 義隆 ${ }^{* 1}$ ，杉村 延広*3
}

\section{A study on education planning method for human operators considering production plans}

\author{
Koji IWAMURA $^{* 1}$, Daisuke NISHIHAMA ${ }^{* 2}$, Kentaro TANAKA ${ }^{* 1}$, \\ Yoshitaka TANIMIZU ${ }^{* 1}$ and Nobuhiro SUGIMURA ${ }^{* 3}$ \\ ${ }^{{ }^{*},{ }^{* 3}}$ Osaka Prefecture Univ. Graduate School of Engineering \\ Gakuen-cho 1-1, Naka-ku, Sakai, Osaka, 599-8531 Japan \\ ${ }^{* 2}$ Kobelco Eco-Solutions Co., Ltd. \\ 4-78, 1-chome, Wakinohama-cho, Chuo-ku, Kobe, 651-0072, Japan
}

Received 13 December 2013

\begin{abstract}
This paper deals with an education planning method of human operators considering production plans. The human operators carry out machining operations by using manual machine tools based on their skills in target manufacturing systems. The individual human operators can obtain new skills to operate the machine tools by receiving trainings. New education planning method is proposed based on mixed integer programming problems in this research. The mixed integer programming problem determines suitable numbers of the trainings and that of the machining operations executed by the human operators for productions. Objective functions of the mixed integer programming problem are minimizing overtime hours and maximizing sum of training priorities. The training priorities represent indices of required skills according to production plans, and number of the skills which have already been obtained. Some case studies have been carried out to verify the effectiveness of the proposed education planning method.
\end{abstract}

Key words : Education planning methods, Production plans, Mixed integer programming problems, Human operators

\section{1. 緒言}

ものづくり産業の経営環境は厳しく, 求められる製品の高品質・高精度化，短納期化，国内・海外企業との価 格競争の激化, 差別的・独創的な製品・技術の必要性などの課題を抱えている. 今後, ものづくり産業が発展し ていくためには，それを担う中核人材の育成・確保や技能継承が重要となる（Health, Labour and Welfare Ministry， 2009).ものづくり産業における人材育成，技能継承に関する研究が多数行われている．例えば，上田ら（上田他， 1999）は，作業者が熟練者のレベルに近づくためには，形式知の獲得に併せて，熟練者のもつ暗黙知を獲得する ことが重要であるとしている，そこで，製造工程などで作業者が試行錯誤を重ねるタスクにおいて，熟練者から 作業者一伝達可能な暗黙知を考え, 模倣するために有益な情報を効率よく伝達する手法を提案している．また， 奥井ら（奥井, 井原, 2007）は，作業者の技能の質の違いは認知能力・情報処理能力の限界の違いにあると考え， $\mathrm{CAM}$ ソフトによる $\mathrm{NC}$ 加工プログラムの作成を対象として, 初心者と中級者の技能の質の違いに適合した CAM ソフトを構成・供給することができる技能向上支援生産システムを提案している. これらの研究は，技術・技能 の定量化およびその伝承方法に焦点を当てた研究と言える.

一方，厚生労働省が我が国の企業，事業所および労働者の能力開発の実態を明らかにすることを目的として行 っている能力開発基本調査（厚生労働省, 2012）において, 人材育成に関する問題点として「指導する人材が不足

\footnotetext{
* 論文 No. 13-00857 [DOI: 10.1299/transjsme.2014trans0144]

${ }^{* 1}$ 正員, 大阪府立大学（干599-8531 大阪府堺市中区学園町 1-1）

*2 (株) 神鋼環境ソリューション（†651-0072 兵庫県神戸市中央区脇浜町 1 丁目 4-78）

*3 正員, フェロー, 大阪府立大学

E-mail of corresponding author: iwamura@me.osakafu-u.ac.jp
} 
している」および「人材育成を行う時間がない」の回答割合が特に高い，したがって，生産活動を行っている作 業者に対して，誰にいつどのような技能を教育するかを適切に計画する教育計画の作成が，人材育成を行うため の重要な課題の一つである. 教育計画に関する従来の研究として, 舘野ら（舘野，清水，2007）は，大型機械や設 備のメンテナンス作業を対象として, 作業者の通常業務のスケジュールの中に, 必要な技能を獲得するための OJT 教育のスケジュールを組み込む手法を提案している．この手法は，作業者が持つ技能で通常業務を行うか，新し い技能を獲得するための OJT を受けるかを決定する敉育值を調整し, エージェントベースのスケジューリングを 実行することで，ジョブの納期を遵守寸るスケジュールを作成することができる．ただし，ジョブの納期を遵守 するスケジュールを作成するためには, 通常業務と OJT の頻度を調整するための適切な教育值を, スケジューリ ングを繰り返しながら試行錯誤的に求める必要がある.

本研究では，作業者が工作機械を用いて加工プロセスを実行する加工システムにおいて，作業者が通常の生 産活動を行いながら，空き時間を利用して自習による研修を行い新たな技能を獲得する状況を対象とする．この とき，作業者が生産計画を遵守しながら生産活動を行い，かつ今後の生産計画で必要となる技能を獲得すること を目的として，混合整数計画問題に基づいて教育計画を作成する手法を提案する. 本研究で提案する教育計画の 作成手法では，生産計画が与えられている複数の期間において，作業者に教育を行うことにより期間の進行とと もに生産性を上げることで，残業時間を考慮しながら必要な生産量を確保することができると考える.

\section{2. 教育計画のための加エシステムの前提条件}

教育計画の作成手法を提案するために，前提条件を以下のように与える.

（1）教育計画で決定する事項は，各作業者の通常の生産活動の作業回数および技能教育のための研修回数と し，スケジューリングなどの生産の実行段階における計画は対象としない.

（2）一定期間における製品の生産計画が立てられている.

（3）作業者は工作機械を用いて製品を加工寸る．各機械を使用するためには技能が必要であり，各技能には 作業者の能力の段階を表す技能レベルがある.

（4）製品の加工時間は技能レベルにより異なる.

（5）作業者は研修を規定回数受けることで新しい技能レベルを習得できる．1回の研修は，定められた研修時 間を確保できる場合にのみ行え，1回の研修を分割して行うことはできない．また，1期間中の技能レベ ルの上昇は 1 つまでとし, 技能を習得するまでの研修の回数は, 機械の種類と技能レベルにより異なる.

（6）各作業者の勤務時間が定められている．ただし，規定された時間内において残業を行うことができる. 以上の前提条件に基づいて，教育計画に必要な入力情報および設計変数を，次のように与える.

I . 入力情報

$V_{p q} \quad:$ 期間 $p(=1,2, \ldots, P)$ における製品 $q(=1,2, \ldots, Q)$ の生産量.

$D_{q r} \quad:$ 機械 $r(=1,2, \ldots, R)$ による製品 $q$ の加工作業を実行するために必要な技能レベル。 $D_{q r}$ は 3 段階からな り，２は高度，1 は通常の技能レベルを必要とすることを，０は製品 $q$ に機械 $r$ の加工作業が必要ない ことを示す，すなわち，正の值を取る場合は，製品 $q$ の完成には機械 $r$ での加工作業が必要であるこ とを意味する.

$D_{1 q r} \quad:$ 製品 $q$ の機械 $r$ による加工作業を実行するための技能レベルが 1 の場合を 1 とするバイナリ変数.

$D_{2 q r} \quad:$ 製品 $q$ の機械 $r$ による加工作業を実行するための技能レベルが 2 の場合を 1 とするバイナリ変数.

$S_{p i r} \quad$ : 期間 $p$ における作業者 $i(=1,2, \ldots, I)$ が持つ機械 $r$ の技能レベル. $S_{p i r}$ は 3 段階からなり, 2 は高度, 1 は通常の技能レベルを持つことを，0 は技能レベルを持たないことを示す．

$S_{1 p i r} \quad:$ 期間 $p$ における作業者 $i$ が持つ機械 $r$ の技能レベルが 1 の場合を 1 とするバイナリ変数.

$S_{2 p i r} \quad:$ 期間 $p$ における作業者 $i$ が持つ機械 $r$ の技能レベルが 2 の場合を 1 とするバイナリ变数.

$T_{p i q r} \quad:$ 期間 $p$ における作業者 $i$ の製品 $q$ の機械 $r$ を用いた加工時間.

$A_{p i r} \quad:$ 期間 $p$ において作業者 $i$ が機械 $r$ の次の技能レベルを習得するために必要な研修の残り回数.

$E_{r} \quad:$ 機械 $r$ の技能の研修 1 回に要寸る時間.

$F_{p i} \quad:$ 期間 $p$ における作業者 $i$ の勤務時間. 
$A D_{p i} \quad$ : 期間 $p$ における作業者 $i$ の残業時間の上限.

$\tau \quad$ : 加重移動平均を用いて生産計画を評価する期間の長さ.

$\omega_{p i r} \quad:$ 期間 $p$ における作業者 $i$ が機械 $r$ の技能の研修を受ける優先度 $\left(0 \leqq \omega_{p i r} \leqq 1\right)$.

$\alpha, \beta \quad$ : 優先度を決定するために用いる 0.1 以上 1 以下の定数.

$W \quad$ : 混合整数計画問題で用いる重み $(0 \leqq W \leqq 1)$.

II. 設計変数

$x_{\text {piqr }} \quad$ : 期間 $p$ において作業者 $i$ が製品 $q$ の機械 $r$ の作業を行う回数 (0 以上の整数).

$y_{p i r} \quad:$ 期間 $p$ において作業者 $i$ が機械 $r$ の技能の研修を行う回数 (0 以上の整数).

$L_{p i} \quad$ : 期間 $p$ における作業者 $i$ の遊休時間.

$O_{p i} \quad$ : 期間 $p$ における作業者 $i$ の残業時間.

ただし， $D_{q r}, D_{1 q r}, D_{2 q r}, S_{p i r}, S_{1 p i r}$ および $S_{2 p i r}$ には以下の関係がある.

$$
\begin{aligned}
& D_{q r}=D_{1 q r}+2 D_{2 q r} \\
& S_{p i r}=S_{1 p i r}+2 S_{2 p i r}
\end{aligned}
$$

\section{3. 生産計画を考慮した作業者の教育計画の作成手法}

\section{$3 \cdot 1$ 教育計画の作成手順}

本研究で提案する教育計画の作成手法は, 各期間 $p(=1,2, \ldots, P)$ を対象として混合整数計画問題に基づいて教 育計画を作成することで期間全体の教育計画を作成する，提案する教育計画の作成手法は以下の手順により実行 する.

STEP1 2 章に示した教育計画に必要な情報を入力する. また，教育計画を作成する期間を $p=1$ とする.

STEP2 STEP3 で用いる優先度 $\omega_{p i r}$ を決定する. 優先度 $\omega_{p i r}$ の求め方は 3.3 節に示す.

STEP3 期間 $p$ を対象として教育計画を作成する. また，得られた教育計画の結果から作業者 $i$ が持つ機械 $r$ の 技能レベル $S_{p i r}$ を更新する.

STEP4 計画の対象とする期間が最終期間 $(p=P)$ の場合は終了する. そうでない場合は，期間を $p=p+1$ とし て STEP2 へ戻る.

\section{$3 \cdot 2$ 混合整数計画問題に基づく生産回数および作業回数の決定}

STEP3 では，以下の混合整数計画問題に基づいて作業者が通常の生産作業を行う回数および研修を行う回数を 決定する.

$$
\operatorname{minimize} W \sum_{i=1}^{I} O_{p i}-(1-W) \sum_{i=1}^{I} \sum_{r=1}^{R} \omega_{p i r} y_{p i r} E_{r}
$$

subject to

$$
\begin{aligned}
& \sum_{q=1}^{Q} \sum_{r=1}^{R} T_{p i q r} x_{p i q r}+\sum_{r=1}^{R} E_{r} y_{p i r}+L_{p i}-O_{p i}=F_{p i} \quad i=1, \ldots, I \\
& \sum_{i=1}^{I} x_{p i q r} \delta_{p i q r}=V_{p q} \phi_{q r} \\
& q=1, \ldots, Q \quad r=1, \ldots, R \\
& 0 \leqq O_{p i} \leqq A D_{p i} \\
& i=1, \ldots, I \\
& y_{\text {pir }} \leqq A_{\text {pir }} \\
& i=1, \ldots, I \quad r=1, \ldots, R \\
& \delta_{p i q r}= \begin{cases}1 & \left(S_{p i r} \geqq D_{q r}\right) \\
0 & \left(S_{p i r}<D_{q r}\right)\end{cases}
\end{aligned}
$$




$$
\begin{aligned}
& \phi_{q r}=\left\{\begin{array}{cc}
1 & \left(D_{q r} \geqq 1\right) \\
0 & \left(D_{q r}=0\right)
\end{array}\right. \\
& x_{p i q r} \geqq 0, y_{p i r} \geqq 0, L_{p i} \geqq 0, O_{p i} \geqq 0 \\
& x_{p i q r} \in \boldsymbol{Z}, \quad y_{p i r} \in \boldsymbol{Z}
\end{aligned}
$$

式（3）は目的関数である．第 1 項は，各作業者の残業時間の和を表し，第 2 項は，各作業者が実行する研修の 時間と優先度の積の和を表す。また，重み $W$ に適切な值を与えることで，残業時間の増加を抑制するか優先度の 高い研修の実行を促すかを調整する. 式（4）〜（11）は制約条件式である. 式（4）は，各作業者について，作 業時間，研修時間，遊休時間，および残業時間の和が勤務時間の制約を受けることを表している. 式（5）は，各 製品に対する各機械を用いた作業者全体の作業回数が，生産量を満たすために必要な作業回数と一致することを 表す. 式（6）は，残業時間の上下限を決める制約である. 式（7）は，1期間における研修の回数を次の技能レ ベルを習得するまでとする制約式である．式（8）は，各製品における各機械の作業について作業者の能力の有無 を示している. 式 (9) は, 各製品において各機械の作業が必要な場合だけ 1 となるバイナリ変数であり，式（10） は非負制約を，式（11）は整数制約を表す.

ここで, 残業には $2 つ の$ 種類がある.1つは通常の生産活動のための残業ともう1つは研修を行うための残業 である. 特に, 後者は本手法の特徵として重要である. 各期間において残業時間を用いて新たな研修を行うかど うかは, 式 (3) の目的関数における重みを用いて調整できる. すなわち, 重み $W=0.5$ の場合は, 優先度が最大 值の 1 となる時，式（3）の第 1 項と第 2 項は等しくなるため研修を行う場合と，行わない場合が混在する. しか し，重み $W>0.5$ の場合は，残業時間を用いて新たに研修を行うと，式（3）の第 1 項が第 2 項より必ず大きくな るため, 残業時間を用いた新たな研修は行わない.

\section{$3 \cdot 3$ 優先度の決定}

式（3）の目的関数における研修の優先度 $\omega_{p i r}$ は，期間 $p$ において作業者 $i$ が機械 $r$ の技能の研修を行うべきか を表す指標であり，生産計画および作業者の技能情報に基づいて決定する，提案する教育計画手法では，優先度 を用いることにより，生産計画により与えられている将来の生産量に対して，必要な技能を特定の作業者に集中 して習得させることで, 生産計画を遵守する. 優先度を決定するために，はじめに，4つのケースについて以下

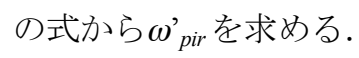

$$
\omega_{\text {pir }}^{\prime}=\left\{\begin{array}{lr}
0 & i=1, \ldots, I \quad r=1, \ldots, R \quad \text { ( case } 1) \quad(12) \\
\sum_{q=1}^{Q}\left(D_{2 q r} \cdot W M A_{p q}\right) /\left\{\max \left(\sum_{i=1}^{I} S_{2 p i r}, \alpha\right) \cdot \sum_{r=1}^{R}\left(S_{1 p i r}+S_{2 p i r}\right)\right\} & i=1, \ldots, I \quad r=1, \ldots, R \quad \text { (case2 }) \\
\sum_{q=1}^{Q}\left(D_{1 q r} \cdot W M A_{p q}\right) /\left[\max \left\{\sum_{i=1}^{I}\left(S_{1 p i r}+S_{2 p i r}\right), \alpha\right\} \cdot \sum_{r=1}^{R}\left(S_{1 p i r}+S_{2 p i r}\right)\right] & i=1, \ldots, I \quad r=1, \ldots, R \quad \text { (case3) } \\
\sum_{q=1}^{Q}\left(D_{1 q r} \cdot W M A_{p q}\right) /\left[\max \left\{\sum_{i=1}^{I}\left(S_{1 p i r}+S_{2 p i r}\right), \alpha\right\} \cdot \beta\right] & i=1, \ldots, I \quad r=1, \ldots, R \quad \text { (case4) }
\end{array}\right.
$$

ここで，WMA $A_{q}$ は，今後の生産計画における全体の生産量に対する製品 $q$ の生産量の割合を表す。 $\omega_{p i r}^{\prime}$ につい て, 基本的な考え方として, 分子の生産計画から求めた今後の生産量に関する情報を, 分母の今後の生産を行う ことができる作業者の人数に関する情報で除することで，作業者 $i$ が機械 $r$ についての研修を受けるべきかの指 標を求めている． $\omega^{\prime}$ pir は, 次元の異なる項の積および商からその值を求めるが, 例えばスケジューリングの分野 において，次元の異なる項の積および商から次に割り当てる作業を求めるディスパッチングルールがあることか ら，ここでは，作業者 $i$ が機械 $r$ についての研修を受けるべきかの指標として $\omega^{\prime}$ pir を提案している.

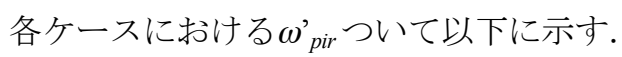


case 1 : 作業者 $i$ が機械 $r$ のレベル 2 の技能を持つ場合

この場合, 作業者 $i$ が機械 $r$ についてレベル 2 の技能を持っているため研修を受ける必要がない. そのため, 優先度は 0 とする.

case 2 : 作業者 $i$ が機械 $r$ のレベル 1 の技能を持つ場合

この場合，分子は，作業者 $i$ が研修によりレベル 2 の技能を習得して製品 $q$ の生産を行う場合を想定して， $W M A_{p q}$ と $D_{2 q r}$ の積から今後の製品 $q$ の技能レベル 2 に関寸る負荷を求め, 全製品についてその和を求めている. 分母は，機械 $r$ のレベル 2 の作業可能な人数と作業者 $i$ が持つ機械の技能の総数との積であり，機械 $r$ のレベ ル 2 の作業可能な人数が少なく, 作業者 $i$ が持つ技能の総数が少ないほど優先度の值は大きくなる. また, 機 械 $r$ のレベル 2 の技能を持つ作業者が一人もいない場合は, 0.1 以上 1 以下の定数 $\alpha$ によ一人以上いる場合と 比べて，優先度の值は大きくなる。

case 3 : 作業者 $i$ が機械 $r$ の技能はもっていないがほかの機械の技能を持っている場合

この場合，分子は，作業者 $i$ が研修によりレベル 1 の技能を習得して製品 $q$ の生産を行う場合を想定して， $W M A_{p q}$ と $D_{1 q r}$ の積から今後の製品 $q$ の技能レベル 1 に関する負荷を求め, 全製品についてその和を求める. 分 母は, 機械 $r$ の作業可能な人数と作業者 $i$ が持つ機械の技能の総数との積であり, 機械 $r$ の作業可能な人数が 少なく，作業者 $i$ が持つ技能の総数が少ないほど優先度の值は大きくなる．また，機械 $r$ の作業可能な人数が 一人もいない場合は, 0.1 以上 1 以下の定数 $\alpha$ にり一人以上いる場合と比べて, 優先度の值は大きくなる.

case4 : 作業者 $i$ が技能を 1 つも持たない場合

この場合, 分子は case 3 と同様とする. また, 分母は, 機械 $r$ の作業可能な人数と 0.1 以上 1 以下の定数 $\beta$ と の積であるため, case 3 と比較して優先度の值は大きくなる. また, case 3 と同様に, 機械 $r$ の作業可能な人数 が一人もいない場合は， 0.1 以上 1 以下の定数 $\alpha$ にり一人以上いる場合と比べて，優先度の值は大きくなる. 式 (12) において, $W M A_{p q}$ は, 今後の生産計画における全体の生産量に対する製品 $q$ の生産量の割合について, 以下の式から線形荷重移動平均を求める.

$$
W M A_{p q}=\left\{\tau \cdot\left(V_{(p+1) q} / \sum_{q=1}^{Q} V_{(p+1) q}\right)+(\tau-1) \cdot\left(V_{(p+2) q} / \sum_{q=1}^{Q} V_{(p+2) q}\right)+\cdots+1 \cdot\left(V_{(p+\tau) q} / \sum_{q=1}^{Q} V_{(p+\tau) q}\right)\right\} \cdot 2 / \tau(\tau+1)
$$

ここで， $\tau$ は線形加重移動平均を求める期間の長さを表す. 式（13）に示す通り，WMA $A_{p q}$ は，次の期間 $p+1$ の加 重を最も大きく, 期間 $p+\tau$ の加重を最も小さくなるように線形に与えている. $W M A_{p q}$ の值が大きいほど, 優先度 を決定するための $\omega_{p i r}^{\prime}$ の值が大きくなる. 本研究では, 優先度を決定する際に, 直近の期間の生産において必要 となる技能を最も重要な技能として習得する一方で，将来の期間において必要となる技能についても習得する必 要があるという観点から, 線形荷重移動平均を用いる.

式（12）で求めた $\omega_{\text {pir }}^{\prime}$ は, 以下の式を用いて 0 から 1 の範囲に正規化し，得られた值を優先度 $\omega_{\text {pir }}$ とする.

$$
\omega_{\text {pir }}=\left\{\omega_{\text {pir }}^{\prime}-\min _{i=1, \cdots, I r=1, \cdots R}\left(\omega_{\text {pir }}^{\prime}\right)\right\} /\left\{\max _{i=1, \cdots, I r=1, \cdots R}\left(\omega_{\text {pir }}^{\prime}\right)-\min _{i=1, \cdots, I r=1, \cdots R}\left(\omega_{\text {pir }}^{\prime}\right)\right\} \quad i=1, \ldots, I \quad r=1, \ldots, R
$$

\section{4. ケーススタディ}

\section{$4 \cdot 1$ 目的関数における重みの検証}

本節では，3.2 節で定式化した混合整数計画問題の目的関数における重み $W$ の設定方法について，ケーススタ ディを行い検証する. ケーススタディの対象として, 作業者 10 名, 製品 10 種類, 機械 10 種類の生産システムに おいて 6 期間の教育計画を作成する場合を考える。なお本研究では，混合整数計画問題を，PC（Core i7-2600K） で IBM ILOG CPLEX ver.12.1 を用いて解いた。

入力情報として，製品の期間ごとの生産量 $V_{p q}$, 期間 1 の開始時点における作業者の技能レベル $S_{p i r}(p=1)$, 製 品の生産に必要な技能レベル $D_{q r}$ を表 1 から表 3 に示す. 表 3 に示す通り, ここでは，生産に必要な技能レベル をすべて 1 以下としている. 
Table 1 Production plan $V_{p q}$

\begin{tabular}{|c|c|c|c|c|c|c|c|c|c|c|}
\hline & \multicolumn{9}{|c|}{ Time periods } \\
\hline & & 1 & 2 & 3 & 4 & 5 & 6 & 7 & 8 & 9 \\
\hline \multirow{10}{*}{$\begin{array}{l}\stackrel{0}{0} \\
\stackrel{D}{0} \\
0\end{array}$} & 1 & 200 & 200 & 200 & 200 & 200 & 200 & 200 & 200 & 200 \\
\hline & 2 & 200 & 200 & 200 & 200 & 200 & 200 & 200 & 200 & 200 \\
\hline & 3 & 200 & 200 & 200 & 200 & 200 & 200 & 200 & 200 & 200 \\
\hline & 4 & 200 & 200 & 200 & 200 & 200 & 200 & 200 & 200 & 200 \\
\hline & 5 & 200 & 200 & 200 & 200 & 200 & 200 & 200 & 200 & 200 \\
\hline & 6 & 200 & 200 & 200 & 200 & 200 & 200 & 200 & 200 & 200 \\
\hline & 7 & 200 & 200 & 200 & 200 & 200 & 200 & 200 & 200 & 200 \\
\hline & 8 & 200 & 200 & 200 & 200 & 200 & 200 & 200 & 200 & 200 \\
\hline & 9 & 200 & 200 & 200 & 200 & 200 & 200 & 200 & 200 & 200 \\
\hline & 10 & 200 & 200 & 200 & 200 & 200 & 200 & 200 & 200 & 200 \\
\hline
\end{tabular}

Table 2 Skill levels of human operators $S_{\text {pir }} \quad(p=1)$

\begin{tabular}{|c|c|c|c|c|c|c|c|c|c|c|c|}
\hline & & \multicolumn{10}{|c|}{ Machine tools } \\
\hline & & 1 & 2 & 3 & 4 & 5 & 6 & 7 & 8 & 9 & 10 \\
\hline \multirow{10}{*}{ 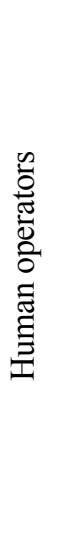 } & 1 & 2 & 1 & 0 & 0 & 0 & 0 & 0 & 0 & 0 & 0 \\
\hline & 2 & 0 & 2 & 1 & 0 & 0 & 0 & 0 & 0 & 0 & 0 \\
\hline & 3 & 0 & 1 & 2 & 1 & 0 & 0 & 0 & 0 & 0 & 0 \\
\hline & 4 & 0 & 0 & 1 & 2 & 1 & 0 & 0 & 0 & 0 & 0 \\
\hline & 5 & 0 & 0 & 0 & 1 & 2 & 1 & 0 & 0 & 0 & 0 \\
\hline & 6 & 0 & 0 & 0 & 0 & 1 & 2 & 1 & 0 & 0 & 0 \\
\hline & 7 & 0 & 0 & 0 & 0 & 0 & 1 & 2 & 1 & 0 & 0 \\
\hline & 8 & 0 & 0 & 0 & 0 & 0 & 0 & 1 & 2 & 1 & 0 \\
\hline & 9 & 0 & 0 & 0 & 0 & 0 & 0 & 0 & 1 & 2 & 1 \\
\hline & 10 & 0 & 0 & 0 & 0 & 0 & 0 & 0 & 0 & 0 & 0 \\
\hline
\end{tabular}

Table 3 Required skill levels for production $D_{q r}$

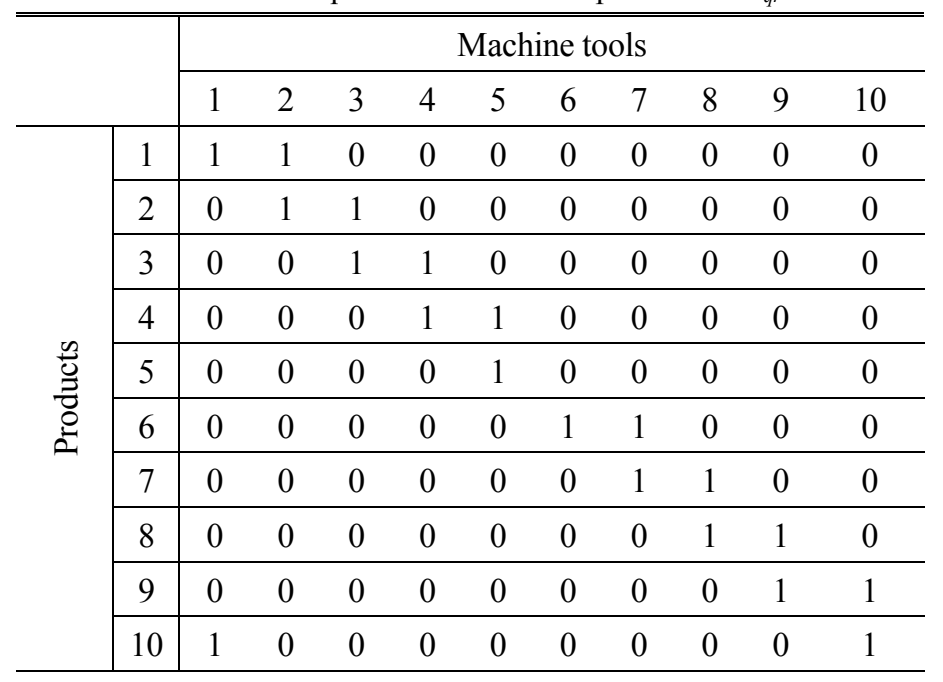


加工時間 $T_{p i q r}$ は, 生産に必要な技能レベル 1 の加工を, 技能レベル 1 の作業者が行う場合はすべて 30 分, 技 能レベル 2 の作業者が行う場合はすべて 20 分とした．作業者の通常の勤務時間 $F_{p i}$ はすべて 9600 分，残業時間 の上限 $A D_{p i}$ はすべて 2400 分とした. 研修 1 回あたりの時間 $E_{r}$ はすべて 120 分とした．次の技能レべルを習得す るために必要な研修の残り回数 $A_{p i r}$ はすべて 30 とした.

混合整数計画問題の目的関数における重み $W$ は，表 4 に示すように 4 パターンの重みの組み合わせを用いた. また，式（12）における優先度を求めるために用いる定数 $\alpha, \beta$ は, 0.1 から 1 までの 0.1 刻みの值として予備実験 を行った結果に基づいて, $\alpha=0.8, \beta=0.3$ とした. 式（13）における線形加重移動平均を求める期間の長さ $\tau$ につ いても予備実験の結果に基づいて $\tau=3$ とした.

ケーススタディの結果として，表 5 に，各期間および全期間における作業者全員の残業時間の合計を，表 6〜9 に，各重みのパターンにおける期間 6 の終了時点（期間 7 の開始時点）における作業者の技能レベルを示す．な お, 表 6 9 において, 灰色で網掛けしている数字は, 表 2 における期間 1 の開始時点の技能と比較して, 新たに 獲得した技能を示している.

重みのパターン $1 \quad(W=1)$ の場合, 残業時間の最小化のみを行い優先度の高い研修の促進は行わない. そのた め, 表 6 から分かる通り, 期間 6 が終了する時点までに新たな技能を獲得する作業者はいない.

重みのパターン2（W=0.51）の場合，優先度の高い研修の促進は行うが，残業時間を用いた新たな研修は行わ ない. 表 7 から分かる通り，作業者は期間 6 が終了する時点までに，新たな技能として，レベル 1 の技能を作業 者全体で 13 個獲得している.また, 表 5 から分かる通り, 重みのパターン 1 と比較して残業時間が減少している. これは, 作業者が研修を行って新たな技能を獲得することで, 短時間で計画された生産量を生産できたためである.

Table 4 Patterns of weights

\begin{tabular}{c|cccc}
\hline \hline & Pattern 1 & Pattern 2 & Pattern 3 & Pattern 4 \\
\hline$W$ & 1 & 0.51 & 0.50 & 0 \\
\hline$(1-W)$ & 0 & 0.49 & 0.50 & 1 \\
\hline
\end{tabular}

Table 5 Overtime hours [min.]

\begin{tabular}{|c|c|c|c|c|c|c|c|}
\hline & \multicolumn{6}{|c|}{ Time periods } & \multirow{2}{*}{ Total } \\
\hline & 1 & 2 & 3 & 4 & 5 & 6 & \\
\hline Pattern 1 & 11440 & 11440 & 11440 & 11440 & 11440 & 11440 & 68640 \\
\hline Pattern 2 & 11440 & 100 & 0 & 10 & 10 & 90 & 11650 \\
\hline Pattern 3 & 11440 & 900 & 80 & 0 & 50 & 4860 & 17330 \\
\hline Pattern 4 & 23990 & 24000 & 23980 & 24000 & 24000 & 24000 & 143970 \\
\hline
\end{tabular}

Table 6 Skill levels of human operators $S_{p i r} \quad(p=7$, Pattern 1)

\begin{tabular}{|c|c|c|c|c|c|c|c|c|c|c|c|}
\hline & & \multicolumn{10}{|c|}{ Machine tools } \\
\hline & & 1 & 2 & 3 & 4 & 5 & 6 & 7 & 8 & 9 & 10 \\
\hline \multirow{10}{*}{ 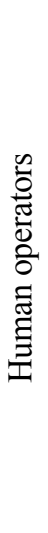 } & 1 & 2 & 1 & 0 & 0 & 0 & 0 & 0 & 0 & 0 & 0 \\
\hline & 2 & 0 & 2 & 1 & 0 & 0 & 0 & 0 & 0 & 0 & 0 \\
\hline & 3 & 0 & 1 & 2 & 1 & 0 & 0 & 0 & 0 & 0 & 0 \\
\hline & 4 & 0 & 0 & 1 & 2 & 1 & 0 & 0 & 0 & 0 & 0 \\
\hline & 5 & 0 & 0 & 0 & 1 & 2 & 1 & 0 & 0 & 0 & 0 \\
\hline & 6 & 0 & 0 & 0 & 0 & 1 & 2 & 1 & 0 & 0 & 0 \\
\hline & 7 & 0 & 0 & 0 & 0 & 0 & 1 & 2 & 1 & 0 & 0 \\
\hline & 8 & 0 & 0 & 0 & 0 & 0 & 0 & 1 & 2 & 1 & 0 \\
\hline & 9 & 0 & 0 & 0 & 0 & 0 & 0 & 0 & 1 & 2 & 1 \\
\hline & 10 & 0 & 0 & 0 & 0 & 0 & 0 & 0 & 0 & 0 & 0 \\
\hline
\end{tabular}


Table 7 Skill levels of human operators $S_{p i r} \quad(p=7$, Pattern 2)

\begin{tabular}{|c|c|c|c|c|c|c|c|c|c|c|c|}
\hline & & \multicolumn{10}{|c|}{ Machine tools } \\
\hline & & 1 & 2 & 3 & 4 & 5 & 6 & 7 & 8 & 9 & 10 \\
\hline \multirow{10}{*}{ 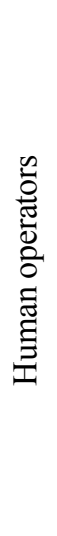 } & 1 & 2 & 1 & 0 & 0 & 1 & 0 & 0 & 1 & 0 & 0 \\
\hline & 2 & 1 & 2 & 1 & 0 & 0 & 0 & 0 & 0 & 0 & 0 \\
\hline & 3 & 1 & 1 & 2 & 1 & 0 & 0 & 0 & 0 & 0 & 0 \\
\hline & 4 & 0 & 0 & 1 & 2 & 1 & 0 & 0 & 0 & 0 & 0 \\
\hline & 5 & 1 & 0 & 0 & 1 & 2 & 1 & 0 & 0 & 0 & 0 \\
\hline & 6 & 1 & 0 & 0 & 0 & 1 & 2 & 1 & 0 & 0 & 1 \\
\hline & 7 & 1 & 0 & 0 & 0 & 0 & 1 & 2 & 1 & 0 & 0 \\
\hline & 8 & 1 & 0 & 0 & 0 & 0 & 0 & 1 & 2 & 1 & 0 \\
\hline & 9 & 0 & 0 & 0 & 0 & 0 & 0 & 0 & 1 & 2 & 1 \\
\hline & 10 & 1 & 0 & 0 & 0 & 0 & 0 & 1 & 0 & 1 & 1 \\
\hline
\end{tabular}

Table 8 Skill levels of human operators $S_{p i r} \quad(p=7$, Pattern 3)

\begin{tabular}{|c|c|c|c|c|c|c|c|c|c|c|c|}
\hline & \multicolumn{10}{|c|}{ Machine tools } \\
\hline & & 1 & 2 & 3 & 4 & 5 & 6 & 7 & 8 & 9 & 10 \\
\hline \multirow{10}{*}{ 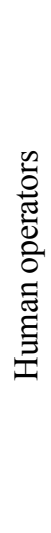 } & 1 & 2 & 1 & 1 & 0 & 1 & 0 & 0 & 1 & 1 & 0 \\
\hline & 2 & 1 & 2 & 1 & 0 & 0 & 0 & 0 & 0 & 0 & 0 \\
\hline & 3 & 1 & 1 & 2 & 1 & 0 & 0 & 0 & 0 & 0 & 0 \\
\hline & 4 & 0 & 0 & 1 & 2 & 1 & 0 & 0 & 0 & 1 & 0 \\
\hline & 5 & 1 & 0 & 0 & 1 & 2 & 1 & 0 & 0 & 0 & 0 \\
\hline & 6 & 1 & 0 & 0 & 0 & 1 & 2 & 1 & 0 & 0 & 1 \\
\hline & 7 & 1 & 0 & 0 & 0 & 0 & 1 & 2 & 1 & 0 & 0 \\
\hline & 8 & 1 & 0 & 0 & 0 & 0 & 0 & 1 & 2 & 1 & 0 \\
\hline & 9 & 1 & 0 & 0 & 0 & 0 & 0 & 0 & 1 & 2 & 1 \\
\hline & 10 & 1 & 1 & 0 & 1 & 1 & 0 & 0 & 0 & 1 & 1 \\
\hline
\end{tabular}

Table 9 Skill levels of human operators $S_{p i r} \quad(p=7$, Pattern 4$)$

\begin{tabular}{|c|c|c|c|c|c|c|c|c|c|c|c|}
\hline & & \multicolumn{10}{|c|}{ Machine tools } \\
\hline & & 1 & 2 & 3 & 4 & 5 & 6 & 7 & 8 & 9 & 10 \\
\hline \multirow{10}{*}{ 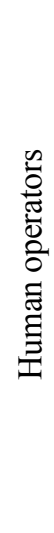 } & 1 & 2 & 1 & 1 & 0 & 1 & 0 & 1 & 1 & 1 & 1 \\
\hline & 2 & 1 & 2 & 1 & 1 & 1 & 0 & 1 & 1 & 1 & 0 \\
\hline & 3 & 1 & 1 & 2 & 1 & 0 & 1 & 1 & 1 & 0 & 1 \\
\hline & 4 & 1 & 1 & 1 & 2 & 1 & 1 & 0 & 0 & 1 & 1 \\
\hline & 5 & 1 & 1 & 1 & 1 & 2 & 1 & 0 & 1 & 0 & 1 \\
\hline & 6 & 1 & 0 & 1 & 0 & 1 & 2 & 1 & 1 & 1 & 1 \\
\hline & 7 & 1 & 1 & 1 & 0 & 1 & 1 & 2 & 1 & 0 & 1 \\
\hline & 8 & 1 & 1 & 1 & 1 & 0 & 0 & 1 & 2 & 1 & 1 \\
\hline & 9 & 1 & 0 & 0 & 1 & 1 & 1 & 0 & 1 & 2 & 1 \\
\hline & 10 & 1 & 1 & 1 & 1 & 1 & 1 & 1 & 1 & 1 & 1 \\
\hline
\end{tabular}


重みのパターン3（ $W=0.50 ）$ の場合, 優先度の高い研修の促進を行い, 残業時間を用いて新たな研修を行う場 合がある. 表 8 から分かる通り，作業者は期間 6 が終了する時点までに，レベル 1 の技能を 17 個獲得しており， これは重みのパターン 2 より多い. ただし, 表 5 から分かる通り残業時間は, 重みのパターン 2 と比較して増え ている．これは，研修のために残業する時間が増えているためである．また，表 5 において期間 6 の残業が増え ていることがわかる. 本ケーススタディでは, 作業者 $i$ が機械 $r$ について技能レベル 1 を獲得している場合は, 式（12）から求める $\omega_{p i r}^{\prime}$ の值が 0 となる. そのため, 期間の後半ほど技能レベル 1 を獲得している作業者が増え ることで，0以外の值を持つ $\omega_{p i r}^{\prime}$ のバリエーションが減り， $\omega_{p i r}^{\prime}$ が同じ值となる場合が増える。これにより多く の優先度が 1 となる場合が発生しやすくなる．期間 6 では優先度が 1 となる場合が多く, 重みのパターン 3 では 残業時間を用いて新たな研修を行う場合があるため残業が増えている.

重みのパターン4（W=0）の場合，優先度の高い研修の促進のみを行い，残業時間の最小化は行わない．表 9 から分かる通り，作業者は期間 6 が終了する時点までに，レベル 1 の技能 56 個を獲得しており，すべてのパター ンにおいて最も多い。 また, 表 5 から分かる通り, 残業時間も最も多い.

また，表 10 に，各期間における目的関数の值および計算時間を全期間で合計した值を示す．表 10 の計算時間 の結果から，すべての重みの組合せにおいて，全 6 期間の計算が短時間で完了していることが分かる.

\section{$4 \cdot 2$ 特定の製品および期間の生産量が多い場合の教育計画の作成}

本研究で提案する手法の有効性を検証するために，特定の製品および特定の期間の生産量が多い場合の教育計 画の作成を行った．特定の製品の生産量が多い場合（case a) および特定の期間の生産量が多い場合（case b), そ れぞれの製品の期間ごとの生産量 $V_{p q}$ を表 11 および表 12 に示す. それ以外の入力情報は, すべて 4.1 節と同じと した。 ただし，ここでは残業時間を用いて新たな研修を行わない場合のみを対象とすることとし，混合整数計画 問題の目的関数における重みは, $W=0.51$ とした. 4.1 節と同様に, 提案手法を用いて 6 期間の教育計画を作成し た.

Table 10 Objective function values and computation times

\begin{tabular}{c|cc}
\hline \hline & Sum of objective function values & Computation times [s] \\
\hline Pattern 1 & 68640 & 11 \\
\hline Pattern 2 & -26566 & 11 \\
\hline Pattern 3 & -55220 & 12 \\
\hline Pattern 4 & -178599 & 15 \\
\hline
\end{tabular}

Table 11 Production plan $V_{p q}$ (case a)

\begin{tabular}{|c|c|c|c|c|c|c|c|c|c|c|}
\hline & & \multicolumn{9}{|c|}{ Time periods } \\
\hline & & 1 & 2 & 3 & 4 & 5 & 6 & 7 & 8 & 9 \\
\hline \multirow{10}{*}{$\begin{array}{l}\frac{n}{0} \\
\frac{D}{0} \\
0 \\
0\end{array}$} & 1 & 380 & 380 & 380 & 380 & 380 & 380 & 380 & 380 & 380 \\
\hline & 2 & 380 & 380 & 380 & 380 & 380 & 380 & 380 & 380 & 380 \\
\hline & 3 & 380 & 380 & 380 & 380 & 380 & 380 & 380 & 380 & 380 \\
\hline & 4 & 95 & 95 & 95 & 95 & 95 & 95 & 95 & 95 & 95 \\
\hline & 5 & 95 & 95 & 95 & 95 & 95 & 95 & 95 & 95 & 95 \\
\hline & 6 & 95 & 95 & 95 & 95 & 95 & 95 & 95 & 95 & 95 \\
\hline & 7 & 95 & 95 & 95 & 95 & 95 & 95 & 95 & 95 & 95 \\
\hline & 8 & 95 & 95 & 95 & 95 & 95 & 95 & 95 & 95 & 95 \\
\hline & 9 & 95 & 95 & 95 & 95 & 95 & 95 & 95 & 95 & 95 \\
\hline & 10 & 95 & 95 & 95 & 95 & 95 & 95 & 95 & 95 & 95 \\
\hline
\end{tabular}


教育計画を作成した結果，特定の製品および特定の期間の生産量が多い場合のいずれにおいても，期間 6 が終 了した時点においてレベル2の技能を新たに獲得した技能者はいなかった，そのため，式（15）から得られる各 機械において, 期間 1 では持っていなかったレベル 1 の技能を, 現在の期間 $(p=z)$ が終了する時点までに新たに 獲得した作業者の数 $S N$ を, 図 1 および図 2 に示寸.

$$
S N=\sum_{i=1}^{I} S_{1 z i r}-\sum_{i=1}^{I} S_{11 i r} \quad r=1, \ldots, R
$$

Table 12 Production plan $V_{p q}$ (case b)

\begin{tabular}{|c|c|c|c|c|c|c|c|c|c|c|}
\hline & & \multicolumn{9}{|c|}{ Time periods } \\
\hline & & 1 & 2 & 3 & 4 & 5 & 6 & 7 & 8 & 9 \\
\hline \multirow{10}{*}{$\begin{array}{l}\frac{n}{0} \\
\stackrel{0}{0} \\
0 \\
0\end{array}$} & 1 & 150 & 150 & 150 & 150 & 250 & 250 & 250 & 250 & 250 \\
\hline & 2 & 150 & 150 & 150 & 150 & 250 & 250 & 250 & 250 & 250 \\
\hline & 3 & 150 & 150 & 150 & 150 & 250 & 250 & 250 & 250 & 250 \\
\hline & 4 & 150 & 150 & 150 & 150 & 250 & 250 & 250 & 250 & 250 \\
\hline & 5 & 150 & 150 & 150 & 150 & 250 & 250 & 250 & 250 & 250 \\
\hline & 6 & 150 & 150 & 150 & 150 & 250 & 250 & 250 & 250 & 250 \\
\hline & 7 & 150 & 150 & 150 & 150 & 250 & 250 & 250 & 250 & 250 \\
\hline & 8 & 150 & 150 & 150 & 150 & 250 & 250 & 250 & 250 & 250 \\
\hline & 9 & 150 & 150 & 150 & 150 & 250 & 250 & 250 & 250 & 250 \\
\hline & 10 & 150 & 150 & 150 & 150 & 250 & 250 & 250 & 250 & 250 \\
\hline
\end{tabular}

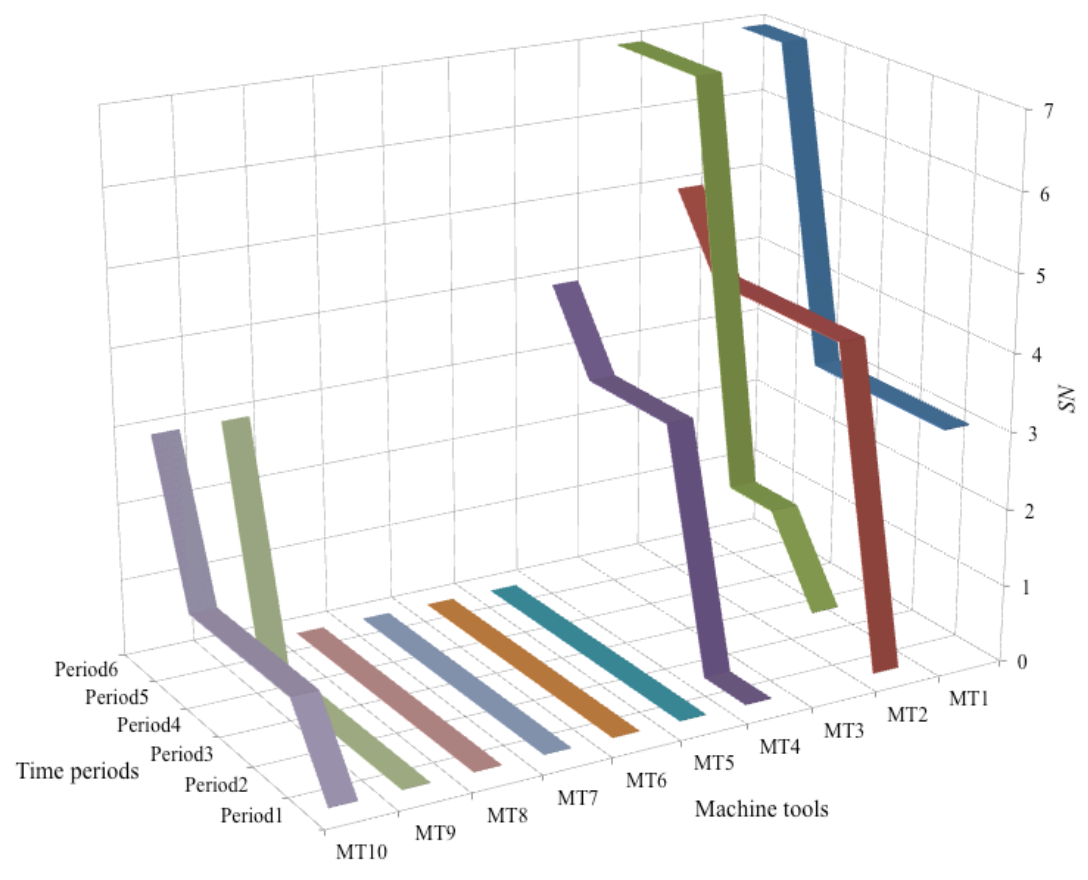

Fig. 1 Each line shows numbers of skills obtained by human operators in case a. Individual human operators obtain new skills of machine tools 1, 2, 3 and 4 which are required to carry out machining processes of products 1, 2 and 3 . 


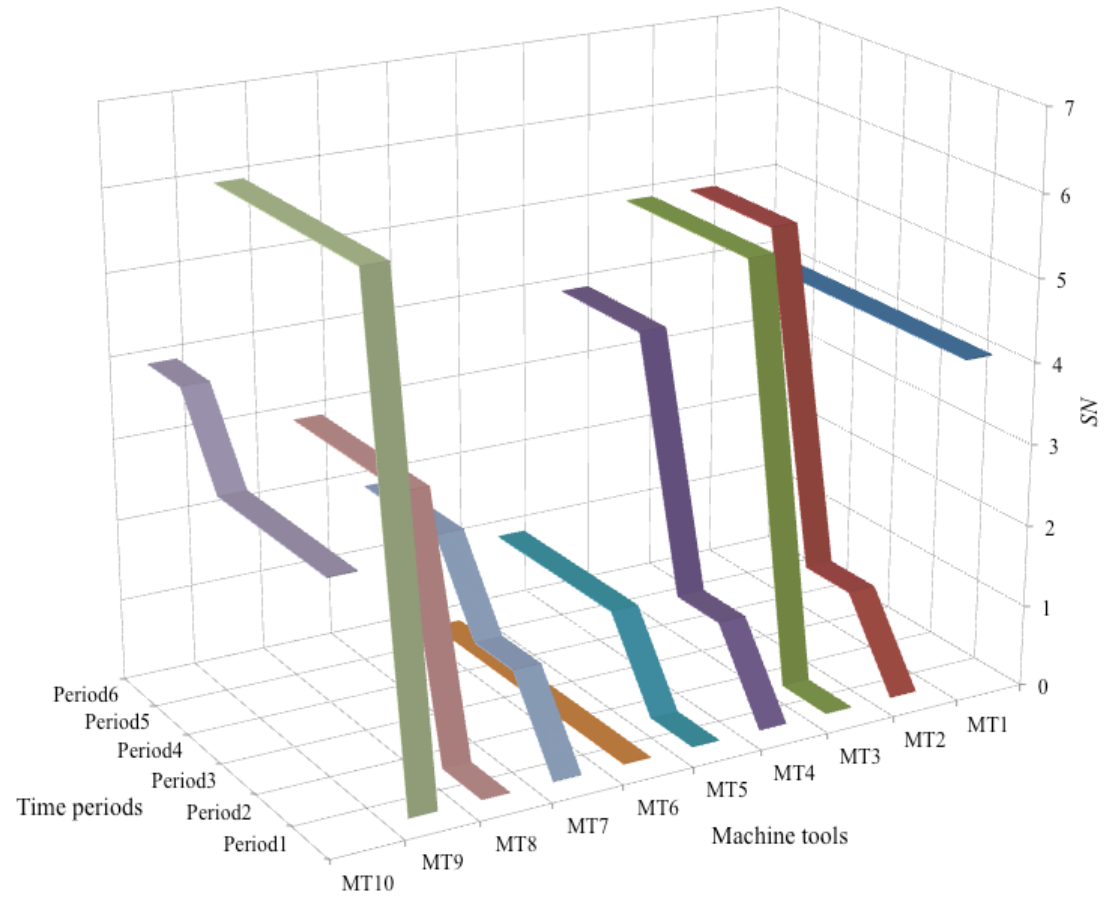

Fig. 2 Each line shows numbers of skills obtained by human operators in case b. Individual human operators obtain enough skills by end of time period 4 in order to carry out a lot of machining processes from time period 5.

特定の製品の生産量が多い場合（case a）について，生産量の多い製品 1 から 3 を生産するためには，表 3 に示 寸通り機械 1 から 4 の技能が必要となる. 図 1 から分かる通り, 各作業者は機械 1 から 4 の技能を多く獲得して いることがわかる．特定の期間の生産量が多い場合に関して，図 2 から分かる通り，各作業者は生産量が増える 期間 4 の終了時点までに, 技能を多く獲得しており, 以降は期間 6 終了時点までに新たな技能の獲得は少ない. すなわち，比較的負担の軽い期間 4 の終了までに，期間 5 以降に必要となる技能を獲得し，期間 5 以降は研修よ り通常の生産活動を優先していることが分かる.

以上から，本研究で提案する教育計画手法を用いることにより，加工システムにおける作業者の教育計画を， 生産計画を考慮して適切に作成できることが分かる.

\section{5. 結 言}

本研究では, 作業者が工作機械を用いて加工プロセスを実行する加工システムを対象として, 混合整数計画問 題に基づいて作業者の教育計画を作成する手法を提案した．以下に本研究の成果をまとめる.

（1）混合整数計画法を用いて，作業者の教育計画を作成する手法を提案した．この手法において，混合整数 計画問題の目的関数を優先度の高い研修の実行と残業時間の最小化，制約条件を生産量，勤務時間など として定式化した。これにより, 定められた勤務時間の範囲で, 生産計画における生産量を遵守しなが ら新たな技能を獲得するための通常の生産活動の回数，および研修の回数を決定することができる.

(2) 混合整数計画問題の目的関数において, 作業者が適切な研修を行うための優先度を提案した. 優先度は, 今後の生産計画および各作業者の技能の情報に基づいて決定する.

（3）提案する教育計画手法を用いて，ケーススタディを行った. はじめに, 混合整数計画問題の目的関数にお ける重みの検証を行い，重みを調整することで研修のために残業時間を用いる場合とそうでない場合を 考慮して，教育計画を作成できることを示した．また，特定の製品および生産量が多い場合について教 育計画を作成し，その結果から提案手法を用いることにより，生産計画を考慮して作業者が適切な技能 を獲得しながら，通常の生産活動を実行する教育計画を作成できることを示した. 


\section{文献}

Health, Labour and Welfare Ministry ed., White Paper on Manufacturing Industries (Monodzukuri) 2009 (Summary 2), (2009), Chapter 3, Section 1.

厚生労働省, 能力開発基本調查 : 結果の概要 (2012), p.12.

奥井洋平，井原透，技能向上支援生産システムにおけるソフトウェア構成法，精密工学会誌，Vol.73, No.1 (2007), pp.161-165.

舘野寿丈，清水慶子，作業者の技能レベルと教育を考慮した作業スケジューリング支援，日本機械学会論文集 C 編, Vol.73, No.734 (2007), pp.216-224.

上田芳弘，加藤直孝，木村春彦，熟練技能者の模倣情報伝達による試行錯誤型タスク支援，電子情報通信学会論 文誌 A, Vol. J82-A, No.5 (1999), pp. 726-735.

\section{References}

Health, Labour and Welfare Ministry ed., White paper on manufacturing industries (Monodzukuri) 2009 (Summary 2) (2009), Chapter 3, Section 1.

Health, Labour and Welfare Ministry ed., Basic survey of human resources development (2012), p.12 (in Japanese).

Okui, Y. and Ihara, T., An innovative proposal for operational software of production system to upgrade worker's skill, Journal of the Japan Society for Precision Engineering, Vol.73, No.1 (2007), pp.161-165 (in Japanese).

Tateno, T. and Shimizu, K., Work scheduling support in consideration of skill level and training of workers, Transactions of the Japan Society of Mechanical Engineers, Series C, Vol.73, No.734 (2007), pp.216-224 (in Japanese).

Ueda, Y., Kato, N. and Kimura, H., A supporting system for the skill acquisition from skilled persons on trial and error-type tasks, The Transactions of the Institute of Electronics, Information and Communication Engineers A, Vol. J82-A, No.5 (1999), pp.726-735 (in Japanese). 